\title{
Why Power Companies Build Nuclear Reactors on Fault Lines: The Case of Japan
}

\section{Citation}

J. Mark Ramseyer, Why Power Companies Build Nuclear Reactors on Fault Lines: The Case of Japan, 13 Theoretical Inquiries in Law 457 (2012).

\section{Published Version}

10.1515/1565-3404.1301

\section{Permanent link}

http://nrs.harvard.edu/urn-3:HUL.InstRepos:30011647

\section{Terms of Use}

This article was downloaded from Harvard University's DASH repository, and is made available under the terms and conditions applicable to Open Access Policy Articles, as set forth at http:// nrs.harvard.edu/urn-3:HUL.InstRepos:dash.current.terms-of-use\#OAP

\section{Share Your Story}

The Harvard community has made this article openly available.

Please share how this access benefits you. Submit a story.

Accessibility 
ISSN 1936-5349 (print)

ISSN 1936-5357 (online)

\title{
HARVARD
}

JOHN M. OLIN CENTER FOR LAW, ECONOMICS, AND BUSINESS

WHY POWER COMPANIES BUILD

NUCLEAR REACTORS ON FAULT LINES:

THE CASE OF JAPAN

\author{
J. Mark Ramseyer
}

Discussion Paper No. 698

$06 / 2011$

Harvard Law School

Cambridge, MA 02138

This paper can be downloaded without charge from:

The Harvard John M. Olin Discussion Paper Series:

http://www.law.harvard.edu/programs/olin_center/

This paper is also a discussion paper of the

John M. Olin Center’s Program on Corporate Governance. 
JEL Classifications: H23, K13, K23, K32

Forthcoming: Theoretical Inquiries in Law Volume 13, Number 2 (July 2012).

J. Mark Ramseyer

Harvard Law School

Cambridge, MA 02138

ramseyer@law.harvard.edu

\title{
Why Power Companies Build Nuclear Reactors on Fault Lines: \\ The Case of Japan
}

\author{
By J. Mark Ramseyer*
}

Abstract: On March 11, 2011, a magnitude 9.0 earthquake and 38-meter tsunami destroyed Tokyo Electric's Fukushima nuclear power complex. The disaster was not a high-damage, low-probability event. It was a high-damage, high-probability event. Massive earthquakes and tsunami assault the coast every century.

Tokyo Electric built its reactors as it did because it would not pay the full cost of a melt-down anyway. Given the limited liability at the heart of corporate law, it could externalize the cost of running reactors. In most industries, firms rarely risk tort damages so enormous they cannot pay them. In nuclear power, "unpayable" potential liability is routine. Privately owned companies bear the costs of an accident only up to the fire-sale value of their net assets. Beyond that point, they pay nothing -- and the damages from a nuclear disaster easily soar past that point.

Government ownership could eliminate this moral hazard -- but it would replace it with problems of its own. Unfortunately, the electoral dynamics in wealthy modern democracies combine to replicate nearly perfectly the moral hazard inherent in private ownership. Private firms will build reactors on fault lines. And so will governments.

* Mitsubishi Professor of Japanese Legal Studies, Harvard University. I received helpful comments and suggestions from Ron Harris, Curtis Milhaupt, Ariel Porat, Frances Rosenbluth, Richard Samuels, Doran Teichman, Frank Upham, Mark West, and participants in a conference at Tel Aviv University. I gratefully acknowledge the generous financial support of the Harvard Law School. I would also like to thank the John M. Olin Center for Law, Economics, and Business at Harvard Law School for the exposure they provide me through their discussion paper series. 


\section{Why Power Companies Build Nuclear Reactors on Fault Lines: The Case of Japan}

\section{(C) 2011 J. Mark Ramseyer. All Rights Reserved}

"We can only work on precedent, and there was no precedent," recalled the engineer who ran the Fukushima Daiichi complex in the 1990s. The massive earthquake and tsunami along the Sanriku coast on March 11, 2011, would throw three of the six reactors at the complex into melt-down mode. "When I headed for the plant, the thought of a tsunami never crossed my mind." 1

The New York Times took the Fukushima director's words at face value. "Japanese engineers working on nuclear plants continued to predict what they believed were maximum earthquakes based on records," it explained. That approach "did not take into account serious uncertainties like faults that had not been discovered or earthquakes that were gigantic but rare." ${ }^{2}$ By way of large past earthquakes, all it could find was the magnitude 8.3 Jogan quake from 869 A.D.

Who could they be kidding?

This is not what we lawyers call "rocket science," and the last earthquake in northeastern Japan was not the 869 Jogan disaster. The Sanriku coast is famously like California: big earthquakes hit it often, hit it regularly, and hit it with massive tsunami. ${ }^{3}$

\begin{tabular}{llll} 
Date & Magnitude & Epicenter & Tsunami. \\
\hline 1611 & 8.1 & N39.0 E144.4 & $15-25$ meters \\
1793 & 8.4 & N38.5 E144.5 & $4-5$ meters \\
1896 & 8.0 & N39.5 E144.0 & 28.7 meters \\
1933 & 8.1 & N39.2 E144.5 & 38.2 meters \\
2011 & 9.0 & N38.3 E142.4 & 38.9 meters
\end{tabular}

Coming about 80 years after the last spectacular quake, the March 2011 earthquake resembled a Tokyo commuter train: faultlessly on schedule. It was bigger than quakes in the past, but its predecessors had been plenty big too. And it brought with it a tsunami almost exactly the height of its predecessor eight decades before.

As long ago as 1934, Akitune Imamura of the Tokyo Imperial University Seismological Institute could write that "the eastern coast of the locality popularly known as the San-Riku (three-Riku) district ... is well known from historic times as the region frequently visited by tunami." What is more, he continued, "it is most notorious in this country, if not in the whole world."

\footnotetext{
${ }^{1}$ Onishi \& Glanz, Japanese Rules for Nuclear Plants Relied on Old Science, N.Y. Times, Mar. 26,
} 2011.

2 Id.

${ }^{3}$ See T. Usami, Nihon higai jishin soran, [416]-2001 [Materials for Copmprehensive List of Destructive Earthquakes in Japan, [416]-2001] (2003); T. Utsu, et al., eds., Jishin no jiten [Encyclopedia of Earthquakes] App. II (2d ed., 2010); Utsu, Nihon fukin no M6.0 ijo no jishin oyobi higai jishin no hyo: 1885 nen - 1980 nen [Table of Magnitude 6.0 or Higher Earthquakes Near Japan and of Earthquakes Causing Damage], 57Jishin kenkyujo iho 401 (1982).

\footnotetext{
${ }^{4}$ Imamura, Past Tsunamis of the Sanriku Coast, 11 Japanese J. Astronomy \& Geophysics 79, 79
} (1934). 
Every century a massive (magnitude $8+$ ) earthquake hits the Sanriku coast, and every century it brings a devastating (typically 20+ meters) tsunami. Any seismologist knew this. Any Sanriku fisherman knew this. And blithely, Tokyo Electric placed ten nuclear reactors on the coast.

Blithely -- but rationally and not recklessly. Tokyo Electric is a corporation. Necessarily, corporate law caps its effective liability at the fire-sale value of its net assets. Because that maximum falls far short of the social costs of a nuclear melt-down, Tokyo Electric will not pay the full cost of running these reactors. Instead, it can use the law to externalize the cost of doing business. It and the other power companies built nuclear reactors that could not survive expected earthquakes. But they did not do so foolishly. They did so because the limited liability at the heart of the corporate law made it profitable to do so.

Government ownership would seem to eliminate this moral hazard. If the government as owner earns the returns to nuclear power generation, it also bears the costs. But only "seem to eliminate" -- for the electoral dynamics of modern wealthy democracies replicate almost exactly the moral hazard behind Fukushima. Combine regulated electricity rates, NIMBY politics, and progressive income taxation -- and government ownership will give voters incentives as mis-aligned as anything faced by Tokyo Electric.

In the article that follows, I use nuclear power in Japan as a case study of moral hazard under private and government ownership. In Section I.A., I survey electricity generation in Japan. In I.B., I explain the basics of nuclear power, and in I.C. outline its regulation in Japan. In Section II, I describe the litigation over nuclear power, and in Section III I discuss the moral hazard involved. The explanation I posit is not specific to Japan -- but neither is the phenomenon of dangerously built and operated reactors.

\section{Nuclear Power in Japan}

A. The Power Industry:

Japan does not have much coal. It does not have much oil, and it does not have much natural gas. It does have steep rivers, and it does dam them to produce electricity. But the rivers do not suffice. All told, hydroelectric plants produce only 7 percent of the electric power Japan needs. ${ }^{5}$

Lacking fossil fuels, Japan imports massively. Yet this reliance on imported fuel leaves it vulnerable in the extreme. It felt this vulnerability most painfully during the 1970s. In 1973, the principal Arab oil producers announced a boycott of countries that supported Israel. They included Japan on their list. Oil prices quadrupled, and Japanese GDP growth promptly turned negative. ${ }^{6}$

Yet the 1973 embargo could not cause Japan to turn nuclear -- because Japan had already turned. Already in the 1950s, the government had started planning for nuclear power. Under its leadership, the electric power companies formed a joint venture and launched a commercial nuclear power plant in 1966.

\footnotetext{
5 World Nuclear Ass'n, Nuclear Power in Japan, Feb. 24, 2011. www.worldnuclear.org/info/inf79.html.

6 Shakai jitsujo deeta zuroku [Social Data in Figures] (2011). www2.ttcn.ne.jp/honkawa/4400.html.
} 
The Arab embargo did cause the Japanese government to tighten its nuclear focus. It had worries enough protecting its oil tankers from pirates in the Malacca Straits. It did not need to mortgage its foreign policy to an Arab cartel. And so, Japan built reactors (see Table 1). Other rich countries built them too, of course. But from its 50+ reactors, Japan new obtains nearly 30 percent of its electricity. ${ }^{7}$

[Insert Table 1 about here.]

The Japanese government does not own these reactors. Neither does it itself dam rivers, burn coal, or build commercial reactors. Instead, privately owned and operated firms produce the energy. In 2010, ten utility companies generated the bulk of the electricity used (see Table 2). All ten firms listed their stock on the Tokyo Stock Exchange. Tokyo Electric was the largest. As of January 2011, it had a market capitalization of 3.2 trillion yen (at 80 yen/\$, about $\$ 40$ billion).

[Insert Table 2 about here.]

\section{B. Nuclear Power:}

1. Thermal reactors. -- Consider nuclear reactors a complicated way to boil water. To produce electricity from uranium, reactors split the atom, radiate heat, generate steam, and spin a turbine. The reactors first cause neutrons to collide with ${ }^{235} \mathrm{U}$. The ${ }^{235} \mathrm{U}$ atom absorbs the neutron, and divides into two smaller atoms. In the process, it releases energy (to create steam), gamma radiation (to cause radiation sickness), and free neutrons (to collide with other uranium atoms).

Before neighboring ${ }^{235} \mathrm{U}$ atoms will absorb the free neutrons, a thermal reactor must slow the neutrons. To do so, most modern reactors hold their fuel assemblies in water -- hence the term "light water reactors." The technology does economize on shipping raw materials: one ton of uranium generates as much electricity as 17,000 to 20,000 tons of coal. But most uranium will not work as fuel. Most of it comes in the stable ${ }^{238} \mathrm{U}$ form. To create a chain reaction in a reactor, a power company must first "enrich" that ${ }^{238} \mathrm{U}$ with the unstable ${ }^{235} \mathrm{U}$ isotope to about 3 to 8 percent. ${ }^{8}$

2. Breeder reactors. -- From the start, the Japanese government planned not to stop with "thermal nuclear reactors" but to move to "fast breeder reactors" (FBRs). ${ }^{9}$ FBRs generate more fissile material than they consume (hence the term "breeder"; because they do not slow their neutrons in water, they are "fast"). As a result, they promised to let Japan skirt the problems caused by its lack of uranium.

${ }^{7}$ In May 2011, the German government decided to decommission all of its reactors by 2022. See Bernd Radowitz \& Jan Hromadko, Germany Moves Forward on Nuclear Exit, Wall St. J., June 6, 2011; Kamei, Fukushima daiichi genpatsu jikogo no yoso [Predicting What Will Follow the Fukushima Daiichi Nuclear Reactor Accident], 1880 Toki no horei 41, 43 (2011). In the same month, Chubu Electric agreed to stop the operation of its Hamaoka plant, pending review of its seismological risks. See Mari Iwata \& Mitsuru Obe, Japanese Power Firm to Shut Nuclear Plant, Wall St. J., May 10, 2011.

${ }^{8}$ World Nuclear Association, Nuclear Power Reactor Characteristics (2010), www.worldnuclear.org/about/; Karam, How Do Fast Breeder Reactors Differ from Regular Nuclear Power Plants?, Scientific American, July 17, 2006, at 13.

${ }^{9}$ See E.g., Pickett, Japan's Nuclear Energy Policy: From Firm Commitment to Difficult Dilemma Addressing Growing Stocks of Plutonium, Program Delays, Domestic Opposition and International Pressure, 30 Energy Policy 1337, 1337-39 (2002); R. Samuels, The Business of the Japanese State 236 (1987); Suzuki, supra note, at 53. 
FBRs burn "mixed oxide" (MOX) fuel. Typically, MOX includes about fourfifths uranium dioxide and one-fifth plutonium dioxide $\left(\mathrm{PuO}_{2}\right)$. Rather than the rare ${ }^{235} \mathrm{U}$, FBRs use the fissile ${ }^{239} \mathrm{Pu}$. Plutonium is extraordinarily dangerous, but for the power companies it is almost-readily available. They can obtain it from two sources. Most obviously, FBRs produce it. A utility can take an FBR's spent fuel to a "reprocessing plant," extract the plutonium, and use it to run the next reactor. ${ }^{10}$

Second, old bombs contain it. Both the U.S. and Russia have large stockpiles of nuclear weapons, and these bombs have plutonium warheads. Take the warheads to a reprocessing plant, mix the weapons-grade plutonium with uranium, and the utilities will have MOX. ${ }^{11}$

The utilities can also burn the MOX in their light-water thermal reactors. Modify the equipment, and even these thermal reactors will run on MOX. The reactor at Fugen (Fukui prefecture) was the first in the world to do so. ${ }^{12}$ Within the Fukushima Daiichi complex, the No. 3 reactor (which, like reactors 1 and 2 spiraled into a partial melt-down) burned plutonium-enriched MOX.

FBRs aggravate the proliferation problem. The reactors produce plutonium and the reprocessing plants mix it into MOX, but terrorists and governments can also load it into bombs. In 1974, India used the plutonium from its FBR to build a "peaceful nuclear explosion." France uses its FBR to create weapons-grade plutonium. The more FBRs, the more chance a rogue regime or terrorist will steal plutonium for a bomb. In part for that reason, the U.K., Germany, and the U.S. have all abandoned their FBR projects. ${ }^{13}$

And FBRs do explode. Because water would decelerate neutrons in the way that would obstruct the FBR's chain reaction, FBRs cool their fuel with liquid sodium. Unfortunately, as one commentator put it, sodium "reacts violently with water and burns if exposed to air." As a result, any leak in the cooling mechanism can cause "a major sodium-water fire." ${ }^{14}$ What is more, that sodium can be highly radioactive.

The reprocessing plants that accompany FBRs create their own problems besides. To turn a FBR's spent fuel into MOX, a utility must "reprocess" the fuel. Unfortunately, that procedure presents its own risk of accidents and proliferation. Sensing those problems, President Jimmy Carter stopped all spent-fuel reprocessing in the U.S. in $1977 .^{15}$

These are serious problems, but Japan has persevered. It has built two FBRs. It placed the Joyo experimental FBR in service in 1977, and the Monju FBR in service in 1994. It built one reprocessing plant in Tokai-mura, mid-way between the Fukushima complex and Tokyo, and a second plant in Rokkasho on the northern tip of Honshu island.

${ }^{10}$ See, e.g., Karam; von Hippel, Overview: The Rise and Fall of Plutonium Breeder Reactors, in T. Cochran, et al., eds., Fast Breeder Reactor Programs: History and Status, International Panel on Fissile Materials, Feb. 2010, at 1; Khodarev, Liquid Metal Fast Breeder Reactors, 20 IAEA Bull. 29 (1978).

${ }^{11}$ Becker \& Broad, New Doubts about Turning Plutonium into a Fuel, N.Y. Times, Apr. 10, 2011.

${ }^{12}$ WNA, 2011, supra note, at 4.

13 von Hippel, 2010, supra note, at 10-11.

${ }^{14}$ von Hippel, 2010, supra note, at 8.

${ }^{15}$ See Karam, supra note. 


\section{Regulatory Structure}

1. Licensing. -- The Ministry of Economy, Trade \& Industry (METI; formerly MITI) licenses reactors. With a unitary (rather than federal) structure and a parliamentary (rather than presidential) government, Japan seems to present power companies with a more stream-lined process than the U.S. In 1995, Linda Cohen, Mathew McCubbins and Frances Rosenbluth cited this institutional structure to explain the greater use of nuclear power in Japan. "U.S. utility companies have all but abandoned nuclear power," they wrote; "Japanese nuclear capacity has mushroomed." U.S. utilities face "myriad bureaucratic hurdles [to] overcome to build new nuclear power facilities"; Japanese firms "face relatively few such impediments." ${ }^{16}$

A power company begins the Japanese licensing process by picking a site. ${ }^{17}$ It completes an environmental impact statement. It assembles its technical plans. It contacts METI, and the ministry consults with the Nuclear Power Commission and the Nuclear Safety Commission (NSC). If METI likes the application, the power company starts building. When finished, it submits the reactor to yet more inspections and testing. Typically, it gives local residents a chance to speak, and the popularly elected prefectural governor has some say as well.

Reactors bring massive subsidies, jobs, and tax revenue. In 2004 METI published a pamphlet to generate support for new nuclear plants. ${ }^{18}$ From the initial environmental impact statement to operation ten years later, it promised a community total subsidies of 39.1 billion yen -- this on top of the construction jobs the reactors would bring. Once operational, it promised additional subsidies and revenues over ten years of 50.2 billion yen. To communities that took nuclear waste sites, it offered even more.

But if the Japanese government presents utilities with a more streamlined process than the U.S., it does not present an effortless process. METI may promise communities massive subsidies, but many refuse the money. Sometimes they hold local votes on a proposed reactor, even when the results do not formally bind. Sometimes their governor blocks construction. Sometimes they sue the power company and METI. Opponents usually win the local elections, but almost never win the lawsuits. Even if they

${ }^{16}$ Cohen, McCubbins \& Rosenbluth, The Politics of Nuclear Power in Japan and the United States, in P. Cowhey \& M. McCubbins, eds., Structure and Policy in Japan and the United States 177, 177-78 (1995).

${ }^{17}$ See generally Cohen, McCubbins \& Rosenbluth, supra note, at 182-83; Shuto, "Minshu jishu kokai" ni hansuru tetsuzuki [Procedures Violating "Democracy, Autonomy, and Openness"], 417 Hogaku seminaa 34 (1989); Genshiryoku hatsuden gijutsu kiko, Genshiryoku hatsudensho no anzen shinsa [The Safety Inspection of Nuclear Reactor Generating Plants] (2003). The process follows statutes relating to the electrical power industry generally and to the nuclear power industry specifically: primarily, the Kaku genryo busshitsu, kaku nenryo busshitsu oyobi genshiryo no kisei ni kansuru horitsu [Law Regarding the Regulation of the Quality of Nuclear Raw Materials, Nuclear Fuel and Nuclear Reactors], Law No. 166 of 1957, Secs. 23, 24, 37, and the Denki jigyo ho [Electrical Business Act], Law No. 170 of 1964, Secs. 47, 49, 51, 52, 54, 107, and the Kankyo eikyo hyoka ho [Environmental Impact Evaluation Act], Law No. 81 of 1997. The process is still very much like the early 1990s process that Cohen, McCubbins \& Rosenbluth described.

${ }^{18}$ Keizai sangyo sho shigen enerugiii cho, Dengen ricchi seido no gaiyo -- Heisei 15 nendo daikaiseigo no aratana kofukin seido [An Outline of the Electrical Generating Sites -- The New Subsidy System After the Great Revision of 2003], Mar. 2004, www.dengen.or.jp. 
eventually lose in court, though, they almost always impose enormous delays (see Section II., below).

2. Earthquake safety. -- When considering a license application, METI evaluates a reactor's ability to withstand an earthquake. The NSC sets the relevant standards. ${ }^{19}$ They vary by location, but in 2006 the NSC revised them to make them more demanding and explicitly to include tsunami risk. ${ }^{20}$

Whether a structure will survive an earthquake depends on a wide variety of factors. Popular writers typically give an earthquake's "magnitude" -- a number on the logarithmic Richter scale. The number represents the amount of energy the earthquake releases. In fact, the danger to a structure depends less on the magnitude itself than on how the ground moves. That movement obviously depends on the quake's "magnitude," but also on its direction, its depth, and the quality of the local soil.

Engineers often give peak ground acceleration in gals ( $\mathrm{cm} / \mathrm{sec}^{2}$; Galileos). Yet even peak acceleration measures the risk to a building only imperfectly. Structural damage depends as much on the duration of any acceleration as on its peak rate. What is more, buildings vibrate at a distinctive "harmonic frequency," and damage also depends on how closely that frequency matches the frequency of the shock waves. ${ }^{21}$

That said, as a crude proxy for the potential damage take the popular Richter scale. The U.S. Geological Service estimates the magnitude of all major earthquakes since the 9th century. ${ }^{22}$ By this measure, the most intense was the 1960 earthquake in Chile with a magnitude of 9.5. The 1964 Alaskan quake had a magnitude of 9.2. The 2004 Indonesian earthquake had a magnitude of 9.1. And the March 20119.0 Japanese earthquake was tied for fourth place with three others. The 1923 Tokyo quake that left 105,000 people dead or missing had a magnitude of 7.9.

3. Liability. -- For damages caused by an accident at a nuclear power plant, the plant's owner is liable by special statute. ${ }^{23}$ By this act, the owner is strictly liable for the full amount of damages. To recover, plaintiffs must demonstrate only the causal connection between the accident and their damages (Sec. II.E., below). The Act

${ }^{19}$ Genshiryoku anzen iinkai, Hatsuden yo genshiryo shisetsu ni kansuru taishin sekkei shinsa shishin [Inspection Manual on Earthquake Resistance Design at Electrical Generating Nuclear Reactor Facilities], Sept. 19, 2006.

${ }^{20}$ Kawai, Higashi nihon daishinsai ni miru genshiryoku hatsudensho no taishin anzensei no kakuho no arikata ni tsuite [Regarding the Way to Insure the Seismological Safety of Nuclear Reactors, as Seen in the Great Eastern Japan Earthquake], 83-5 Horitsu jiho 79 (2011).

${ }^{21}$ Qamar, Earthquake Hazards in the Pacific Northwest (2008), www.crew.org/ep/hazards.html; J. Singh, 2011. Characterization of Ground Motion for Severity and Damage Potential (2011), nisee.berkeley.edu/lessons/singh.html.

22 USGS, Historic World

(2011), earthquake.usgs.gov/earthquakes/world/historical_mag.php.

${ }^{23}$ Genshiryoku songai no baisho ni kansuru horitsu [Law Regarding the Compensation for Nuclear Damages], Law No. 147 of 1961, Sec. 3; Ministry of Education, Culture, Sports, Science \& Technology, Genshiryoku songai baisho seido [Damage Compensation System in Nuclear Power] (2011), www.mext.go.jp/a_menu/anzenkakuho/baisho/index.html (hereinafter MECSST). 
preempts claims under the general tort damage provisions of the Civil Code, ${ }^{24}$ and other firms (like an operator's parent corporation) bear no liability. ${ }^{25}$

To facilitate payment, a plant's operator must maintain both an insurance contract with a private insurer, and a separate contract with the government. Both contracts must cover liability up to 120 billion yen per reactor. ${ }^{26}$ The private insurer will cover most accidents. The contract with the government will cover those accidents caused by events (like earthquakes and tsunami) that private insurers typically exclude. Should all this prove insufficient, the statute also authorizes the government to provide additional assistance (obviously, the government could choose to do so without that statute anyway). ${ }^{27}$

For "extremely massive natural disasters" the reactor's operator is not liable. This is not a phrase the courts have yet interpreted. Whether the March 11 earthquake exempts Tokyo Electric thus remains unclear.

\section{Nuclear Power and the Courts}

A. Introduction:

Although power companies still find it easier to license new reactors in Japan than in the U.S., the process is no longer as clean as when Cohen, McCubbins \& Rosenbluth wrote in the early 1990s. People near the plants regularly sue. They manipulate land titles to prevent power companies from building. They challenge the licenses. They try to enjoin the plants from operating.

In the end, nuclear opponents almost always lose in court. Yet even when they lose, they introduce massive delays -- sometimes, decades. Delays matter. In Japan as elsewhere, time is money.

\section{B. Fukushima:}

1. Introduction. -- Take Tokyo Electric and its now-infamous Fukushima reactors. The firm located the Daiichi (the name means "Number One") plant along the eastern coast of Japan, 140 miles north of Tokyo. By March 2011, the plant had six reactors with a total capacity of 4,546 MWe. It located the Daini (meaning "Number Two") plant 7 miles south. There, it maintained another four reactors with 4,268 MWe capacity.

Tokyo Electric placed the first of the Fukushima reactors (No. 1 at the Daiichi complex) in service in 1971. With an expected life of 40 years, the reactor was in its last days. ${ }^{28}$ It placed the last (No. 4 at Daini) in service in 1985. When the March earthquake hit, the Daini reactors shut down without incident. The tsunami reached only 7 meters

${ }^{24}$ Ibaragi kotsu, K.K. v. K.K. JCO, 1876 Hanrei jiho 34 (Tokyo D. Ct. Sept. 27, 2004), aff'd on other grounds, 1914 Hanrei jiho 95 (Tokyo High Ct. Sept. 21, 2005). To same effect: Kono v. K.K. JCO, 2003 Hanrei jiho 67 (Mito D. Ct. Feb. 27, 2008).

${ }^{25}$ E.g., Kono v. K.K. JCO, 2003 Hanrei jiho 67 (Mito D. Ct. Feb. 27, 2008).

26 Genshiryoku songai baisho hosho keiyaku ni kansuru horitsu [Law Regarding the Supplementary Nuclear Power Damage Compensation Contract], Law No. 148 of 1961, Secs. 7, 8; MECSST, supra note..

${ }^{27}$ Nuclear Compensation Act, Sec. 16(a); Genshiryoku, 2006, supra note; MECSST, supra note.

28 Digital World Portal, Fukushima Nuclear Power Plant, Mar. 18, 2011. edigitales.org/fukushima-nuclear-power-plant/ 
high, and the quake brought peak acceleration rates of 196 to 305 gal. These remained comfortably within the reactors' limits of 415 to 512 gal.

Tokyo Electric's problems occurred instead at the Daiichi complex. The firm had designed its reactors to withstand peak horizontal acceleration of 415 to 489 gal. It had anticipated a 5.7 meter tsunami. In fact, the peak acceleration during the March 2011 earthquake hit 550 gal, and the wave slammed the complex at 14-15 meters high. ${ }^{29}$

2. Landfill. -- Nuclear-power opponents had begun fighting the Fukushima reactors in court in the early 1970s. In 1973, the governor of Fukushima licensed Tokyo Electric to fill part of the local bay. The firm needed to do this to build the Daini complex. Neighbors challenged the landfill license, and the court dismissed their claim for lack of standing. They contested the safety of the nuclear plant, it noted, but the statute at stake did not concern reactor safety. It concerned landfills. They might well have standing to contest the reactor's operating license, but none to challenge the landfill. $^{30}$

3. Reactor license. -- Opponents did contest Tokyo Electric's operating license -for nearly two decades, all the way to the Supreme Court. In 1975, about 400 neighbors to Daini sued METI's predecessor ministry over the reactor's license. The trial took years. In 1984, the Fukushima District Court held that they had standing to challenge the license, and added that the government bore part of the burden of showing the rationality of its decision. It concluded that the government had met its burden, and dismissed the case. ${ }^{31}$

The Sendai High Court affirmed in 1990, and the Supreme Court in 1992: the neighbors had standing to sue, but lost on the merits. ${ }^{32}$ To ensure their safety, the ministry had specifically considered earthquake risk. To be sure, the district court noted magnitude 7.7 earthquakes in 1646 and 1938. Given that Tokyo Electric had properly planned for a 7.7 quake, however, the reactor was safe. The magnitude $8.0+$ quakes that came every century? Apparently, the courts defined them out of the relevant geographical area.

4. Other suits. -- Neighbors fought the Fukushima complex through other suits too. They bought stock in Tokyo Electric. When the cooling system in one of the Daini reactors malfunctioned in 1989, they sued as shareholders to shut it down. Only then, they argued, could the firm avoid irreparable harm to itself.

${ }^{29}$ Tokyo Electric Power Co., Higashi Nihon daishinsai ni okeru genshiryoku hatsudensho no eikyo to genzai no jokyo ni tsuite [Regarding the Effect of the Great Eastern Japan Earthquake on the Nuclear Electrical Generating Plant and its Present Circumstances], May 2011, www.tepco.co.jp.

${ }^{30}$ Onoda v. Matsudaira, 894 Hanrei jiho 39 (Fukushima D. Ct. June 19, 1978).

${ }^{31}$ Onoda v. Okonogi, 1124 Hanrei jiho 34 (Fukushima D. Ct. July 23, 1984), aff'd, 1345 Hanrei jiho 33 (Sendai High Ct. Mar. 20, 1990), aff'd, 1441 Hanrei jiho 50 (Sup. Ct. Oct. 29, 1992); see generally Yasui, Genpatsu sosho ni okeru rissho sekinin [Burden of Proof in Nuclear Reactor Litigation], 2010 Kyushu L. Assn. J. 33 (2010).

32 Onoda v. Okonogi, 1345 Hanrei jiho 33 (Sendai High Ct. Mar. 20, 1990), aff'd, 1441 Hanrei jiho 50 (Sup. Ct. Oct. 29, 1992). 
The court dismissed their claim. Whether to restart a damaged reactor was a question on which the firm's board could turn to specialists. If those specialists thought it appropriate to restart the reactor, it could properly restart it. ${ }^{33}$

When Tokyo Electric modified reactor 3 at the Daiichi plant to use plutoniumenriched MOX, neighbors sued again. Plutonium was dangerous, they argued. They did not want it in their backyard. They filed for an injunction, and in 2001 the court dismissed their claim: MOX was safe. ${ }^{34}$

\section{Reactor Licensing:}

1. Introduction. -- The Fukushima opinions typify Japanese anti-nuclear litigation. Neighbors sue, claiming a threat to their health. They ask the court to shut down the reactor. Provided they live close enough, the courts grant them standing. They then dismiss on the merits: the reactors are safe.

2. Shiga. -- But not always. One of the few (temporary) exceptions to this rule involved the Shiga reactor complex on the Japan Sea shore. First, anti-nuclear activists sued to enjoin the operation of reactor 1 . In 1994, they won on standing and lost on the merits. The district court noted the risk of powerful earthquakes, but held that the reactor could withstand them. The high court and Supreme Court affirmed. ${ }^{35}$

Activists then sued to enjoin reactor 2. This time -- in 2006 -- the district court granted the injunction. It recited some of the past earthquakes: a magnitude 7.9 quake in 745, 8.1 in 1586, 6.8 in 1729, 7.1 in 1858, 8.0 in 1891, 6.4 in 1892, 6.0 in 1933. It discussed ground acceleration and harmonic frequency. And where the agency had announced that the reactor needed to be able to withstand a magnitude 6.5 quake, the court disagreed. The agency could not reasonably limit the reactor's potential exposure to so small an earthquake. ${ }^{36}$

The opinion did not last. On appeal, the high court in 2009 held the reactor safe. $^{37}$ The power company bore part of the burden of showing that the reactor was safe, but it met it. The plaintiffs lost on the merits.

3. Monju. -- The other (equally temporary) exception to the rule involved the Monju FBR. Four Japanese firms (not utilities) organized a joint venture to build the reactor, and in 1980 applied for a permit. They obtained it in 1983. Opponents then sued MITI to void the permit. The Fukui District Court dismissed their claim for lack of

\footnotetext{
${ }^{33}$ Hirose v. Nasu, 1591 Hanrei jiho 3 (Tokyo D. Ct. Dec. 19, 1996), affirmed 1686 Hanrei jiho 33 (Tokyo High Ct. Mar. 25, 1999).

${ }^{34}$ [No name given] v. Tokyo denryoku, K.K., 1775 Hanrei jiho 114 (Fukushima D. Ct. Mar. 23, 2001) (Fukushima 1).

${ }^{35}$ Kawabe v. Hokuriku denryoku, K.K., 1515 Hanrei jiho 3 (Kanazawa D. Ct. Aug. 25, 1994), affirmed, 1656 Hanrei jiho 37 (Nagoya High Ct. Sept. 9, 1998), affirmed (Supreme Ct. Dec. 19, 2000).

${ }^{36}$ [No names given], 1930 Hanrei jiho 25 (Kanazawa D. Ct. Mar. 24, 2006).

${ }^{37}$ [No names given], 2045 Hanrei jiho 3 (Nagoya High Ct. Mar. 18, 2009), reversing (Kanazawa D. Ct. Mar. 24, 2006).
} 
standing, but on appeal the Nagoya High Court granted standing to those nearest the plant. In 1992 the Supreme Court expanded the group with standing, and remanded the case. ${ }^{38}$

Meanwhile, construction continued. In 1991 the developers started testing the reactor, and by 1994 had launched a self-sustaining chain reaction. By August of 1995 they were generating electricity. Promptly, however, a thermometer in the cooling system broke and ruptured the sodium heat transfer system. A massive fire engulfed the room. No one was injured and no radioactivity leaked, but the temperatures spiked so high that the steel melted. The government shut down the reactor. ${ }^{39}$

With standing settled, the district court heard evidence on reactor safety. It canvassed the history of earthquakes in the area, and concluded that the reactor was safe. The opponents appealed again, and in 2003 the Nagoya High Court reversed. The safety studies were flawed and -- therefore -- the reactor's license was void. Yet this order too did not last. The defendants appealed to the Supreme Court, and two years later the Court reversed. The safety study was fine, the administrative process had been reasonable, and the courts should defer to the agency. ${ }^{40}$

4. Other plants. -- More typically, courts simply grant standing and dismiss on the merits from the outset. Neighbors to the Onagawa reactor 100 miles north of Fukushima Daiichi sued to halt construction and enjoin operation. As elsewhere, the courts held that they had standing, but decided against them on the merits: the reactor was safe. ${ }^{41}$

Neighbors similarly sued to challenge licenses for the Ikata reactor (Ehime prefecture), Tokai-mura reactor (Ibaragi), Takahama reactor (Fukui), Tomari-mura reactor (Hokkaido), and Kashiwazaki reactor (Niigata). In each case, the courts held that they had standing to sue, but dismissed their claims. In each case, the courts concluded that the reactors were safe. ${ }^{42}$

${ }^{38}$ Isobe v. Takeshita, 1264 Hanrei jiho 31 (Fukui D. Ct. Dec. 25, 1987), reversed, 1322 Hanrei jiho 33 (Nagoya High Ct. July 19, 1989), modified, Tokioka v. Miyazawa, 1437 Hanrei jiho 29 (Sup Ct. Sept. 22, 1992).

${ }^{39}$ See Pickett, supra note, at 1342; Suzuki, supra note, at 54.

${ }^{40}$ [No name given], 1727 Hanrei jiho 33 (Fukui D. Ct. Mar. 22, 2000), reversed, 1818 Hanrei jiho 3 (Nagoya High Ct. Jan. 27, 2003), reversed, 1909 Hanrei jiho 8 (Sup. Ct. May 30, 2005).

${ }^{41}$ Abe v. Tohoku denryoku, K.K., 1482 Hanrei jiho 3 (Sendai D. Ct. Jan. 31, 1994), affirmed, 1680 Hanrei jiho 46 (Sendai High Ct. Mar. 31, 1999).

42 Kawaguchi v. Fukuda, 891 Hanrei jiho 38 (Matsuyama D. Ct. Apr. 25, 1978)(Ikata), affirmed, Kawaguchi v. Murata, 1136 Hanrei jiho 3 (Takamatsu High Ct. Dec. 14, 1984), affirmed, Inoue v. Watanabe, 1441 Hanrei jiho 37 (Sup Ct. Oct. 29, 1992); [No name given], 1057 Hanrei taimuzu 87 (Matsuyama D. Ct. Dec. 15, 2000)(Ikata); Aizawa v. Murata, 1164 Hanrei jiho 3 (Mito D. Ct. June 25, 1985), affirmed in relevant part, 1754 Hanrei jiho 35 (Tokyo High Ct. July 4, 2001) (Tokai-mura); Smith v. Kansai denki, K.K., 1480 Hanrei jiho 17 (Osaka D. Ct. Dec. 24, 1993) (Takahama); Shigeno v. Hokkaido denryoku, K.K., 1676 Hanrei jiho 3 (Sapporo D. Ct. Feb. 22, 1999) (Tomari-mura); Nagasawa v. Kumagaya, 1489 Hanrei jiho 19 (Niigata D. Ct. Mar. 24, 1994), affirmed, 52 Somu geppo 1581 (Tokyo High Ct. Nov. 22, 2005) (Kashiwazaki).

These are just the published opinions. News reports indicate that neighbors have sued in other cases as well. The Oct. 26, 2007, decision of the Shizuoka District Court in the litigation over the Hamaoka reactor can be found on the website of the plaintiffs: www.geocities.jp/ear_tn/. 
Residents near other nuclear facilities have fared no better. One group of plaintiffs challenged the license on a low-level nuclear waste facility. Another group challenged the license to the Rokkasho enrichment facility. Both groups lost on the merits. $^{43}$

\section{Other Litigation: ${ }^{44}$}

1. Land. -- Opponents have also tried to block power companies from buying the land they needed. Take the planned reactor in the town of Maki in Niigata prefecture. In 1996, residents voted against Tohoku Electric's project, and elected a mayor opposed to it. He sold the site that Tohoku had planned to use to an anti-nuclear investor who then refused to sell. The reactor's supporters tried to void the transfer to the opponent, but the courts upheld the sale. ${ }^{45}$ In due course, Tohoku Electric abandoned its plans. ${ }^{46}$

Other opponents have argued that a sale of land for use for a reactor was void as against the "public order and good morals" requirement of the Civil Code. ${ }^{47}$ When one group of opponents tried to block a transfer on that ground, the utility sued. The court declared reactors safe, and enforced the transfer. ${ }^{48}$

Still others have argued that the land a utility wanted was held "in common" by members of the village. Unless all members agreed to sell, the sales contract was void. As villagers do hold some rural land in common, the question for the courts has been whether a single opponent could block a transfer. In one case, the utility sued to partition

${ }^{43}$ [No name given], 1278 Hanrei taimuzu 97 (Aomori D. Ct. June 16, 2006); [No names given], 1102 Hanrei taimuzu 79 (Aomori D. Ct. Mar. 15, 2002), affirmed, Hanrei taikei 28131668 (Sendai High Ct. May 9, 2006).

${ }^{44}$ Opponents can embroil power companies in litigation over a wide range of other issues as well. For example, they may sue the firms to force disclosure of materials related to reactor safety: Abe v. Tohoku denryoku, K.K., 1452 Hanrei jiho 3 (Sendai D. Ct. Mar. 12, 1993) (disclosure required), affirmed, 1460 Hanrei jiho 38 (Sendai High Ct. May 12, 1993), affirmed, Hanrei taikei 28060382 (Sup. Ct. Dec. 19, 2000); Miki v. Kawaguchi, 786 Hanrei jiho 3 (Takamatsu High Ct. July 17, 1975) (disclosure required); Aizawa v. Prime Minister, 43 Somu geppo 1522 (Tokyo High Ct. Dec. 25, 1996) (disclosure not required). They sue over procedural inadequacies: Oba v. Japan, 1741 Hanrei jiho 139 (Hakodate D. Ct. July 13, 2000). They sue to block utilities from doing what they need to complete their license application: Iwo jima gyogyo kyodo kumiai v. Chugoku denryoku, K.K., 916 Hanrei taimuzu 237 (Yamaguchi D. Ct. Oct. 11, 1995) (land survey). They sue to block sympathetic governments from helping the utilities: Hashi v. Nakanishi, 1429 Hanrei jiho 46 (Kanazawa D. Ct. Mar. 22, 1991) (environmental impact statement); [No names given], 45 Gyosei jiken saibanrei shu 1112 (Asahikawa D. Ct. Apr. 26, 1994), affirmed, 48 Gyosai reishu 393 (Sapporo High Ct. May 5, 1997) (waste disposal study).

45 Takai v. Sasaguchi, 217 Hanrei chiho jiji 59 (Niigata D. Ct. Mar. 16, 2001) (dismissing challenge to sale), affirmed, 237 Hanrei chiho jiji 96 (Tokyo High Ct. Mar. 28, 2002).

${ }^{46}$ Genpatsu baburu ni tayoranai machi ye [Toward a Town that Will Not Rely on the Nuclear Power Bubble], Shinbun akahata, Dec. 31, 2003 (Japan Communist Party newspaper); Tohoku denryoku kabushiki gaisha Maki genshiryoku hatsudensho no genshiryo setchi kyoka shinsei no torisage ni tsuite [Regarding the Withdrawl of the Application for the Establishment of a Nuclear Reactor Electrical Generator at Maki by Tohoku Electric Power Co.], at METI website: www.meti.go.jp/kohosys/press/0004934/

${ }^{47}$ See Minpo [Civil Code], Law No. 89 of 1896, Sec. 90.

${ }^{48}$ Shikoku denryoku, I.K. v. Tamura, 728 Hanrei jiho 27 (Matsuyama D. Ct. Feb. 2, 1974). 
the commonly held land, and buy the section held by those who did not object to the planned reactor. The court allowed the partition. ${ }^{49}$ In another case, the court held that the village in question did not require unanimity. Whether a village required unanimity depended on local custom, and in the case in question the court held that it did not. ${ }^{50}$

2. Plebiscite. -- Or take the reactor complex in Kashiwazaki, 35 miles south of Maki. The giant plant holds seven reactors. In 2001, Tokyo Electric (the owner) decided to use MOX. The residents took a vote, and a majority voted no. They had no legal power to decide what fuel Tokyo Electric would burn. But faced with their opposition, the utility opted to stay with uranium. ${ }^{51}$

3. Derivative claims. Sometimes, opponents of nuclear plants have bought stock in the power company and filed derivative suits. In one case, for example, Chubu Electric had "deposited" a large sum of money with a local fishing cooperative. When a shareholder challenged the deposit, the court dismissed the claim. Chubu would need the support of the cooperative in the future, it explained. Toward that end, this was a reasonable expenditure. $^{52}$

Other opponents have used their status as shareholders to attend its annual meeting. In at least four cases, they then decided that firm management did not pay them sufficient attention, and sued to vacate the results of the meeting. In each case, the court dismissed their claims. ${ }^{53}$

These suits could backfire. When one group of opponents filed a derivative suit, the court told them to post bond. Said the court, they had sued in part in bad faith. They were not pursuing the good of the firm. Instead, they were pursuing their own personal policy (anti-nuclear) preferences. ${ }^{54}$

\section{E. Damage Claims:}

1. Introduction. -- Recall that for all damages caused by a nuclear accident (other than because of massive disasters), the operator is strictly liable. Plaintiffs must show causation, but need not show negligence. Most published opinions on damage claims

49 [No names given], 1918 Hanrei jiho 58 (Aomori D. Ct. May 10, 2005).

${ }^{50}$ [No name given] v. Chugoku denryoku, K.K., 1933 Hanrei jiho 84 (Hiroshima High Ct. Oct. 20, 2005), affirmed, 2007 Hanrei jiho 58 (Sup. Ct. Apr. 14, 2008). See generally Commentary, 1269 Hanrei taimuzu 121 (2008). See also Shibano v. Tokyo denryoku, K.K., 1361 Hanrei jiho 3 (Niigata D. Ct. July 18, 1990) (Kashiwazaki reactor; in commons litigation, all villagers are necessary parties).

51 Jijiro Kashiwazaki shi shokuin rodo kumiai rengo kai, Niigata ken Kashiwazaki Kirihama genpatsu 3 goki no purusaamaru jisshi no kahi wo tou jumin dohyo wo meguru genchi hokoku [Site Report on the Plebecite over the use of MOX in Reactor 3 at the Niigata Prefecture Kashiwazaki Kirihama Reactor 3] (2002), www.jichiro.gr.jp/jichiken/report/rep_tokushima29/jichiken/5/5_2_02.htm.

52 Nakagawa v. Abe, 1652 Hanrei jiho 138 (Nagoya D. Ct. Mar. 19, 1998).

${ }^{53}$ Matsushita v. Kyushu denryoku, K.K., 1392 Hanrei jiho 126 (Fukuoka D. Ct. May 14, 1991); Nakagaki v. Chubu denryoku, K.K., 116 Shiryoban shoji homu 188 (Nagoya D. Ct. Sept. 30, 1993); Shinohara v. Tohoku denryoku, K.K., 109 Shiryo ban shoji homu 64 (Sendai D. Ct. Mar. 24, 1993); Kobayashi v. Hokkaido denryoku, K.K., 109 Shiryo ban shoji homu 56 (Sapporo D. Ct. Feb. 22, 1993).

${ }^{54}$ Nakagawa v. Matsunaga, 892 Hanrei taimuzu 121 (Nagoya High Ct. Nov. 15, 1995). 
concern a 1999 accident at the Tokai-mura enrichment plant, 80 miles northeast of Tokyo. $^{55}$

2. The accident. -- The Tokai-mura plant fabricates nuclear fuel. In 1999, it was mostly enriching uranium for conventional reactors. This process required it to increase the fraction of the ${ }^{235} \mathrm{U}$ isotope in the fuel to 5 percent. ${ }^{56}$

In 1999, the plant agreed to enrich fuel to 18.8 percent ${ }^{235} \mathrm{U}$ for the experimental Joyo FBR. To produce this fuel, workers dissolved enriched uranium oxide. The rules required them to dissolve the oxide in a special tank, transfer the solution to a buffer column, and then move it to a precipitation vat. Through this convoluted process, they could prevent a chain reaction.

The three workers on September 30, 1999, apparently thought this procedure a lot of bother. Rather than follow directions, they dissolved the uranium oxide in buckets, and dumped it directly into the precipitation vat. They had done this with the 5 percent enriched uranium to no apparent ill effect. On September 30, they tried it with the 18.8 percent fuel bound for the FBR.

What worked for 5 percent ${ }^{235} \mathrm{U}$ started a chain reaction with 18.8 percent. At root, the workers seem not to have known what they were doing. The plant had not produced the more highly enriched fuel for three years, and had not trained these men for the job. They handled the 18.8 percent fuel as they did the 5, and started a chain reaction that ran out-of-control for 20 hours. The resulting radiation killed two of the three, and exposed 400 others. $^{57}$

Prosecutors filed criminal charges against the operator JCO, several of its executives, and the surviving malfeasant employee. The district court convicted them all. It fined the firm a trivial 1 million yen (but the firm also lost its license), and sentenced the other defendants to prison terms (suspended). ${ }^{58}$

3. Liability. -- (a) The framework. People began filing claims against JCO (the operator) immediately. To facilitate recovery, JCO agreed to pay half of the claimed amounts before the end of the year on a provisional basis. It would then finalize awards in 2000. During the fall of 1999, it paid 5.4 billion yen in provisional settlements.

A year after the accident, JCO had settled 98 percent of the 7,025 claims. The total cost: 12.73 billion yen. Through the private insurer pool JCO carried the statutorily mandated insurance, but the contract covered only the first 1 billion yen (since raised to

55 World Nuclear Association, Tokaimura Criticality Accident, July 2007, www.worldnuclear.org/info/inf37.html. Two non-Tokai-mura cases are: Karasawa suisan K.K. v. Nihon genshiryoku hatsuden K.K., 1322 Hanrei jiho 99 (Nagoya High Ct. May 17, 1989) (wholesale fish merchants lose because cannot show consumer boycott was tied to radioactive leak); Iwasa v. Nihon genshiryoku hatsuden, K.K., 1032 Hanrei jiho 87 (Osaka D. Ct. Mar. 30, 1981) (worker at reactor loses on health claim when cannot show irradiation).

${ }^{56}$ See Pickett, supra note; International Atomic Energy Agency, Report on the Preliminary Fact Finding Mission Following the Accident at the Nuclear Fuel Processing Facility in Tokaimura, Japan (1999).

${ }^{57}$ OECD, Tokai-mura Accident, Japan: Third Party Liability and Compensation Aspects, Nuclear L. Bull., No. 66, Dec. 2000.

\footnotetext{
58 Japan v. [no names given], 1136 Hanrei taimuzu __ (Mito D. Ct. Mar. 3, 2003).
} 
24 billion yen). It paid what it could of the excess, and its parent corporation paid the rest. $^{59}$

(b) Successful claimants. Settlement talks could stall, of course. Two nearby firms manufactured a fermented soybean paste called "natto." With consumers scared of radioactivity, one of the firms had to close its factory for a time. It sued JCO for 1.59 billion yen, but the court awarded damages of only 180 million yen. Because JCO had paid 213 million yen provisionally, the court ordered the firm to repay the difference. ${ }^{60}$

The second firm also sued for lost sales. JCO had paid it 276 million yen provisionally. Because the court found actual liability of only 166 million, it ordered the firm to repay the 110 million yen excess. ${ }^{61}$

(c) Dismissed claims. The Tokai-mura claimants did not all win in court. Ibaragi kotsu claimed that the accident had slashed the value of its real estate developments. To recover the loss, it sued JCO under both the Nuclear Compensation Act and the tort damage provisions of the Civil Code.

The court dismissed all of Ibaragi kotsu's claims. The Nuclear Compensation Act did cover its claims -- if Ibaragi kotsu could prove them. And because it covered the claims, it also preempted the Civil Code. But to recover, Ibaragi kotsu had to show that the accident caused the value of its real estate to fall. That, said the court, it simply had not done. ${ }^{62}$

Likewise, a couple who ran a small factory near the Tokai-mura complex claimed that the accident had made them sick. Again, the court dismissed their claims. They did not show that they suffered ill effects caused by the accident. ${ }^{63}$

Finally, a frozen foods company claimed that the accident caused consumers to avoid its products. It froze and sold shrimp, crabs, oysters, and other shellfish. Fears of radioactivity, it argued, led consumers to shun its goods. JCO had provisionally paid it substantial damages. The court decided that the company had not proven its damages, and ordered it to repay the entire provisional amount. ${ }^{64}$

III. Ownership and Regulation

A. The Fukushima Reactors:

1. The quake and tsunami. -- Return now to the March 2011 quake and tsunami. On the afternoon of March 11, a magnitude 9.0 earthquake hit northeastern Japan. It struck 45 miles off the coast, 15 miles deep. Tokyo Electric had anticipated peak horizontal acceleration at the Daiichi plant of 489 gal. The March quake shook it at 550

${ }^{59}$ Note that the Mito District Court would later hold that the parent corporation was not liable. Kono v. K.K. JCO, 2003 Hanrei jiho 67 (Mito D. Ct. Feb. 27, 2008).

${ }^{60}$ [No name given]v. K.K. JCO, 1960 Hanrei jiho 64 (Tokyo D. Ct. Apr. 19, 2006)

${ }^{61}$ Takano Fuzu, K.K. v. K.K. JCO, 1207 Hanrei taimuzu 116 (Tokyo D. Ct. Feb. 27, 2006).

62 Ibaragi kotsu K.K. v. K.K. JCO, 1876 Hanrei jiho 34 (Tokyo D. Ct. Sept. 27, 2004), aff'd 1914 Hanrei jiho 95 (Tokyo High Ct. Sept. 21, 2005).

${ }^{63}$ Kono v. K.K. JCO, 2003 Hanrei jiho 67 (Mito D. Ct. Feb. 27, 2008).

${ }^{64}$ Ano v. K.K. JCO, 1830 Hanrei jiho 103 (Mito D. Ct. June 24, 2003). 
gal. ${ }^{65}$ It could have been worse: 90 miles to the northwest, peak acceleration hit 2,933 gal.

A massive tsunami followed. Tokyo Electric had anticipated waves of 5.4 to 5.7 meters. ${ }^{66}$ In fact, the tsunami hit the plant at 14 to 15 meters. Again, it could have been worse: elsewhere, the waves reached 38.9 meters. As of May 2011, Japanese sources put the death toll at 15,000, and listed another 5,000 missing and presumed dead.

2. The plant. -- The Fukushima Daiichi complex held six reactors. Five of them burned enriched uranium, and one (reactor 3) used plutonium-enriched MOX. ${ }^{67}$ At the time of the earthquake, only reactors 1,2 and 3 were running.

The earthquake hit at 2:46 p.m. All three reactors shut down automatically. The quake may have damaged them anyway, though Tokyo Electric claimed not and as of May the matter remained unclear. ${ }^{68}$ What is clear is that the earthquake severed the plant from the national power grid. The Fukushima reactors needed outside power to cool them. Cut from the grid, they had no power. To make good the loss, plant operators fired their back-up diesel generators.

The waves hit at 3:27. They crested the sea-walls, and swamped the reactors. Because Tokyo Electric had placed its back-up generators under the reactors, they swamped the generators too, and swept away the diesel fuel tank. The plant was now without a cooling system.

Quickly, the Daiichi reactors began to heat. At reactor 1 temperatures soared to $2800^{\circ} \mathrm{C}$, and the fuel began to melt. Soon, the fuel at reactors 2 and 3 began to melt as well. Reactors 1,3 and 4 leaked hydrogen. The gas exploded, blew the tops off the reactor housing, and sprayed radioactive particles into the atmosphere. A pool at reactor 2 began to leak, and then the pools at reactors 1, 3 and 4 started to leak too. Some of the radioactive liquid seeped into the ground water. The rest ran into the Pacific. ${ }^{69}$

The air near the reactors began to turn radioactive. Fish caught in the ocean showed radioactivity. Vegetables grown nearby became radioactive. Drinking water in Tokyo showed traces of radioactive iodine. The government evacuated 80,000 people from the area near the reactors, 21 workers at the complex recorded $100 \mathrm{mSv}$ radioactivity exposure, and three went to the hospital. At the Daini plant, one worker died during the disaster. At Daiichi, two died soon, and a third died in May. The

${ }^{65}$ Reactor 2 was rated to 438 gal, but received a shock of 440 gal, reactor 3 was rated to 441 gal but had a shock of 507 gal, and reactor 5 was rated to 452 gal but had a shock of 548 gal. See Kawai, supra note, at 82.

\footnotetext{
${ }^{66}$ Fukushima genpatsu "taju bogi" no amasa rotei [Weakness of Fukushima Nuclear Reactors "multiple Protections" Disclosed], Sankei shimbun, Mar. 28, 2011, sankei.jp.msn.com/affairs/news/110328/dst11032819280054-n1.htm; Japan Wants 3 Reactors Closed While Seawall Built, msnbc.com, May 6, 2011, www.msnbc.msn.com/id/42928264/ns/world_newsdisaster_in_japan/.

${ }^{67}$ Third Japanese Reactor to Load MOX, World Nuclear News, Aug. 10, 2010, www.worldnuclear-news.org/newsarticle.aspx?id=28211.

${ }^{68}$ See Obe \& Dvorak, Core of Japanese Nuclear Reactor Likely Melted, Wall St. J., May 12, 2011.

${ }^{69}$ See Obe \& Dvorak, supra note; Obe, Leaks Probed as Japan Moves to Cool Reactors. Wall St. J., Apr. 26, 2011; Obe, Tepco: Leak Suggests Severe Damage, Wall St. J., May 12, 2011; Obe, Cores Damaged at Three Reactors, Wall St. J., May 16, 2011.
} 
complex is littered with radioactive concrete and debris, and now holds 80,000 tons of radioactive water. ${ }^{70}$

3. De-commissioning the plant. -- At the very least, Tokyo Electric will need to decommission reactors 1 through 4 at the Daiichi complex. Probably, it will decommission all six. Optimists put the cost at 1.5 trillion yen ( $\$ 19$ billion). Others suggest much more. ${ }^{71}$

To retire the Daiichi reactors, Tokyo Electric will need first to install a new cooling system. The current system does not work, and the plant needs a way to avoid a meltdown. After adding that mechanism, the firm will temporarily encase the reactors in a flexible (but radioactivity-proof) tent. It will then build a more permanent structure. ${ }^{72}$

Yet even "permanent" is not forever. Tokyo Electric needs the reactors isolated for 300 years, but concrete does not last that long. During the week after the March earthquake, the New York Times sent a reporter to Chernobyl. In the months after the melt-down, the Soviet government had encased that reactor in a concrete box. The box is "riddled with cracks," reported the journalist. When it rains, water leaks in. It turns radioactive, and workers then pump it out. ${ }^{73}$ The 15,000 square miles around the reactor (roughly the size of Switzerland) will not be livable for three centuries. Instead, the "wild world is gradually pressing its way" back into the area. To replace the Soviet sarcophagus, the Ukrainian government is raising funds. The cost for a new cement box: $\$ 1.4$ billion.

4. Compensating victims. -- The compensation claims started arriving immediately. A month after the accident, local agricultural cooperatives were filing demands. For the fall in price of their vegetables in March, they claimed losses of 1.45 billion yen. For milk they could not sell, they asked 398 million. $^{74}$

But that was just the start. By law -- by the Nuclear Compensation Act -- unless the earthquake was so massive as to exempt Tokyo Electric from all liability (a legal question still unclear), the firm is strictly liable for all damages caused. By contract, the government is liable for the first 120 billion yen ( $\$ 1.5$ billion), but 120 billion yen does

70 METI, News Release, Apr. 2011, www.meti.go.jp/press/2011/04/20110403002/20110403002-1.pdf; Mochizuki, Worker Dies at Japan's Fukushima Plant, Wall St. J., May 14, 2011.

${ }^{71}$ Kamiya \& Nakano, Genpatsu baisho 4 cho en, seifu ga shisan [Government Proposes Budget of 4 Trillion yen for Nuclear Reactor Compensation], Asahi shimbun, May 9, 2011; ANS Nuclear Cafe, Decommissioning Fukushima. ANS Nuclear Cafe, Apr. 7, 2011, ansnuclearcafe.org/2011/04/07/decommissioning-fukushima/.

${ }^{72}$ Belson \& Myers, Tokyo Utility Lays Out Plan for Its Reactors, N.Y. Times, Apr. 17, 2011; ANS, supra note.

73 Barry, Lessons from Chernobyl for Japan, N.Y. Times, Mar. 19, 2011.

74 Ibaragi ken nai no nochikusanhigai, Toden ni 18 okuen baishoseikyu he [1.8 Billion Compensation Demand to Tokyo Electric for Ibaragi Prefecture Agricultural Damages], Nihon keizai shimbun, Apr. 25, 2011; Genpatsu hosho, kuni ga futan mo [Country Too Will Bear Burden of Nuclear Reactor Compensation], Nihon keizai shimbun, Apr. 27, 2011. 
not go far. Estimates of the eventual total vary, but Bank of America Merrill Lynch put it at 2.5-4 trillion yen (\$31-49 billion). ${ }^{75}$ Other observers go higher still.

Tokyo Electric cannot pay 4 trillion yen. Before the accident, it had a market capitalization of 3.2 trillion (Table 2). It had total assets of 13.2 trillion yen, but after outstanding debt net assets of only 2.5 trillion.

All this makes some sort of reorganization likely. If Tokyo Electric is legally liable but unable to pay, the government may pay compensation in the firm's stead. If so, it will probably demand a big stake in the firm. Perhaps it will take an equity stake, or perhaps it will take a debt stake with effective control. As of mid-May, plans remained in flux. $^{76}$

5. The seismological context. -- Recall the historical discussion from the outset of this article. In four centuries, five earthquakes have stuck the area with at least magnitude 8. The 2011 quake came 78 years after its magnitude 8.1 predecessor, and that one arrived 37 years after an 8.0 quake. At 38.9 meters, the 2011 tsunami was almost exactly as high as its 1933 predecessor.

At root, the March 2011 earthquake and tsunami were not large-magnitude, lowprobability disasters; they were large-magnitude, very-high-probability disasters. Seismologists could not have predicted them for 2011, but they could predict them for the first half of the century. They could not have predicted the 9.0 magnitude, but they could predict at least 8 . They could not have predicted a 38.9-meter tsunami, but they could predict at least 20.

The point is simple: the fault off-shore from the Fukushima nuclear complex causes massive and frequent earthquakes. Low-probability events like a 9.0 earthquake can be hard to anticipate. But the issue was not whether Fukushima would see a 9.0 earthquake. It was whether it would see an earthquake of at least magnitude 8.0, and the answer was "yes." It was whether it would see a tsunami at least 20 meters high, and the answer was "yes."

\section{B. Private Ownership:}

1. Moral hazard. -- Tokyo Electric wildly underplayed the risk of a large earthquake and tsunami, but it did not underplay it carelessly or negligently. It underplayed it rationally -- wildly, but rationally. By incorporating, it limited the extent of its liability to the fire-sale value of its net assets. Beyond that amount, any losses fell on its victims -- or, if the government so chose, on taxpayers. Once losses climbed beyond its fire-sale value, Tokyo Electric escaped all liability.

This moral hazard inheres in all privately owned nuclear power companies. These firms are corporations and, necessarily, enjoy limited liability. Cause a disaster, and they face liability capped by the value of their net assets. Beyond that amount, they pay nothing. Necessarily, they have no incentive to limit damages beyond the value of those net assets. For risks beyond that point, they capture all the returns but bear none of the costs.

\footnotetext{
${ }^{75}$ Narioka \& Sekiguchi, Tepco Rescue Plan Could Hit Investors, Wall St. J., May 13, 2011.

${ }^{76}$ Iwata \& Sekiguchi, Japan Fails to Reach Tepco Funding Deal, Wall St. J., May 12, 2011.
} 
In most industries, this dynamic is not a problem. Firms seldom commit torts that cause damages so large as to swamp their net assets. Instead, they retain most of the right incentives on the margin. Banks may have caused large losses in 2008, but most of those losses they imposed on the parties with whom they contracted -- and, necessarily, internalized the risk through the price term in their contract. Silicon breast implant makers internalized any product risk through the market price of the implants. Tobacco firms internalized the risk of cancer through the price of their cigarettes. Asbestos makers internalized the risk of asbestosis through the wages firms paid to workers who handled the material, which in turn affected the price the firms paid the manufacturers for the insulation.

The problem instead arises in those few industries (like nuclear power) where firms can impose massive damages on people (like neighbors) who do not earn a contractual return for bearing that risk. In these industries, firms impose on third-parties a risk of catastrophic damages that easily swamps their net asset value. Necessarily, when making decisions about those investments, they will face the wrong incentives on the margin.

2. Regulatory incentives. -- In theory, regulation could solve this problem. In practice, it does not. One can overstate the point: as one political scientist put it, "the extent to which career bureaucrats are either socialized against the stated missions of their agencies, or guided primarily by venal motives, has been overstated." ${ }^{77}$ Yet however overstated, the problem remains. As George Stigler wrote years ago, regulators do not necessarily regulate in the public interest. Instead, they sometimes regulate in the interest of the firms they regulate: as Stigler put it, "regulation is acquired by the industry and is designed and operated primarily for its benefit."78

This pro-industry bias can come from several sources. Sometimes, regulators adopt the bias because firms bribe them. Sometimes, they adopt it because the firms hire them after they retire. Sometimes, they adopt it because they talk so often with the firm's representatives that they become genuinely convinced.

More basically, regulators regulate in the interests of the regulated firms because they (as agents) work for politicians (as principals). Those politicians, in turn, promote the interests of the regulated firms because the firms have more intense interests at stake than voters at large. Voters care about many things, but care intensely about very few. Because good legislation (or good regulation) is by its nature a public good, voters will seldom organize to promote legislation (or regulation) about matters in which they have but a casual interest. By contrast, for a regulated firm the regulation may indeed be a private good. The firm will care deeply about it, and will lobby heavily to shape it. A power company, for example, will lobby for quicker licensing, lax oversight, and higher rates. In Japan, the power companies were long a major contributor to the then-ruling Liberal Democratic Party. In the U.S., power companies donate to politicians too -- and

\footnotetext{
${ }^{77}$ Gordon \& Hafer, Corporate Influence and the Regulatory Mandate, 69 J. Pol. 300, 302 (2007).

${ }^{78}$ Stigler, The Theory of Economic Regulation, 3 Bell J. Econ. \& Mgmt. Sci. 3 (1971); see Peltzman, Toward a More General Theory of Regulation, 19 J. Law \& Econ. 211 (1976).
} 
Sanford Gordon and Catherine Hafer find that those who do enjoy abbreviated safety inspections at their nuclear plants. ${ }^{79}$

3. Judicial incentives. -- Japanese judges approve the licenses bureaucrats grant for the same reason the bureaucrats grant them: in effect, judges are bureaucrats too. ${ }^{80}$ Bureaucrats at METI work for politicians who regulate in part by Stigler's famous logic. Japanese judges work for the same politicians.

Most Japanese judges join the courts immediately after graduating from the national law school. Most then stay in the courts until their early 60s. During their careers, they move through a series of posts, generally at three-year intervals. They are not indifferent among them. Some posts are in Tokyo, some in Osaka, and some are in provincial small cities. Some posts are in district courts, some in appellate courts, and some in obscure branch offices. Some posts are in prosecutorial bureaus, and some in the court's own administrative offices.

Among these posts, the court's personnel office (known as the "Secretariat") decides where each judge will go. Judges themselves staff the personnel office. There, they report to the Supreme Court. They serve at the Secretariat on one or more of their three-year postings. In this capacity, they read the performance reviews senior judges in the rest of the country write about their colleagues. They then post those judges to positions they (at the Secretariat) consider most appropriate.

Japanese judges also climb the court's pay scale. Although the Constitution protects them against pay cuts, it does not promise them pay raises. Japanese judges start their careers at low pay. If successful, they end their careers at high pay. But how quickly they climb the intervening steps depends on how highly their colleagues in the Secretariat evaluate their work.

Necessarily, this system gives judges strong incentives to decide politically charged cases along the lines favored by politicians in the ruling party. The cabinet names the Supreme Court justices, those justices supervise the judges who run the Secretariat, and the Secretariat judges monitor, evaluate, promote and punish the rest of the court. By naming to the Supreme Court justices who share their policy preferences, the cabinet can ensure that lower court judges tend to adjudicate sensitive cases along ruling party policy lines.

In turn, the way that the Secretariat rewards and punishes judges affects the type of law-school graduate who applies for a judicial position at all. On average, judges who decide controversial cases according to the preferences of ruling party politicians do better than those who do not. In turn, this phenomenon implies that who share those preferences are more likely to enjoy the job of a judge.

\section{Government Ownership:}

${ }^{79}$ Gordon \& Hafer, Flexing Muscle: Political Expenditures as Signals to the Bureaucracy, 99 Am. Pol. Sci. Rev. 245 (2005).

${ }^{80}$ See generally J.M. Ramseyer \& E. Rasmusen, Measuring Judicial Independence: The Political Economy of Judging in Japan (2003). 
Japan (and other countries) could eliminate this moral hazard if the government owned the power plants itself. Private firms may use limited liability to externalize the risk of operating reactors, but governments do not face a liability cap. If they operate a reactor and it makes money, they capture the returns for themselves. If they operate a reactor and it blows up, they pay damages in full. They capture the income, they pay the costs. At every level, they apparently face the correct marginal incentives.

But only "apparently." Even as governments avoid the moral hazard created by limited liability, they replicate it with their own. Perversely in the extreme, the electoral dynamics in modern democracies give politicians nearly identical (and identically misaligned) incentives. The point is not just that governments run firms badly -- though they do run them inefficiently. Neither is the point that the Soviet Union handled Chernobyl badly -- thought it did handle it disastrously. The point is that democratic governments face incentives that are misaligned on almost exactly the dimensions by which Tokyo Electric's incentives were misaligned in Fukushima.

The perverse incentives to government ownership follow from three facets of modern democratic government:

(i) The government sets consumer electrical prices. Whether electricity is generated by private firms or the government, consumers do not buy it at cost. They buy it at prices set by the government. If unregulated firms can compete for segments of the market (e.g., business users), then prices in some sectors may start to reflect market dynamics. In general, though, consumers will buy their power at prices that reflect electoral -- not economic -- criteria.

(ii) NIMBY politics dominate site selection. Again whether electricity is generated by private firms or the government, operators will not build reactors on seismologically optimal sites. They will build them on politically optimal sites. Because melt-downs can be bad even for politicians, seismological considerations will not be irrelevant -- but neither will they be all that matters. Voters care not just about the probability that a reactor will explode in the abstract, but about the probability that it will explode in their backyard. If the seismological optimum is in their backyard, they will want the reactor built on a suboptimal site.

(iii) "Other people" pay the cost of a disaster. Suppose a governmentowned reactor melts down. Citizens will not bear (A) the share of the resulting liability that tracks (B) the share of the benefit they received from the electricity. Instead, a broad range of citizens will enjoy the benefit of stable and cheap electricity, but only a small group will bear the cost of the liability. Necessarily, politicians elected by majority vote have little incentive to equalize expected costs and benefits on the margin.

This perverse result follows straightforwardly from the logic of the progressive income tax. In modern wealthy democracies, a small fraction of taxpayers pays most of the costs of government. If the government is liable for a tort, that small fraction pays the bulk of the liability. In the U.S., 5 percent of the taxpayers pay about 60 percent of the income tax; 10 percent pay about $70 .{ }^{81}$ In

${ }^{81}$ National Taxpayers Union, Who Pays Income Taxes and How Much (2011), ntu.org/taxbasics/who-pays-income-taxes.html. 
Japan, 2 percent of the taxpayers pay about 40 percent of the income tax; 20 percent pay about $80 .^{82}$

As a result, most politicians represent constituents who enjoy the benefits of cheap and stable electricity but would not (under government ownership) pay much of the cost of a nuclear melt-down. They consume a large share of the electricity, but for it pay only regulated (not market) prices. Because they bear but a small fraction of the burden of the public fisc, they bear but a small part of any liability from a nuclear disaster. Hence the moral hazard.

Among firms in competitive economic markets, the managers who survive are those who equalize the costs and benefits to the firm on the margin. Investors price a firm's stock by present-valuing its expected net cash-flow. If managers invest in a project that earns more than it costs, investors bid up the price of the stock. If they invest in a project that costs more than it earns, investors bid it down. Facing more expensive capital costs, the firms whose managers invest in bad projects will either replace those managers or disappear.

Among governments in modern democracies, the politicians who survive are not those who equalize costs and benefits to the country on the margin. Granted, all else equal voters will prefer politicians who choose efficient projects to those who do not. ${ }^{83}$ But all else is not equal, for voters can use the law to allocate the benefits among themselves differentially. Shareholders cannot legally redistribute corporate wealth from other investors to themselves. Voters can use the law to do exactly that. ${ }^{84}$ As a result, voters will not just elect politicians who select projects that generate net positive returns for the country. They will elect politicians who redistribute the national wealth from other voters to themselves.

The implications for nuclear power are straightforward: voters will elect politicians:

(a) who will build enough plants (of any sort) to generate a steady supply of electricity,

(b) who will sell them that electricity cheaply,

(c) who, if they generate that electricity through nuclear reactors, will locate those reactors in someone else's district, and

(d) who will maintain a tax regime in which other people pay the bulk of the public fisc -- and the bulk of the cost of any meltdown.

In the private sector, limited liability drives a wedge between the costs and returns to nuclear power. That wedge then generates the moral hazard behind Fukushima. Under public ownership, the progressive tax rates (coupled with rate regulation and NIMBY siting) similarly drive a wedge between the costs of government projects and their

82 Shotokuzei wa dare ga haratte iru? [Who Pays the Income Tax] (Mar. 18, 2010), http://zei.sagafan.jp/e198676.html.

${ }^{83}$ Becker, A Theory of Competition Among Pressure Groups for Political Influence, 97 Q.J. Econ. 371 (1983).

${ }^{84}$ This is a variation on Richard Epstein's point that the "progressive tax increases the frequency and intensity of legislative rent seeking by increasing the expected gains of factions." R. Epstein, Takings 299 (1985). 
benefits. That wedge then generates a dynamic nearly identical to the moral hazard in the private sector.

Hence the result: regulated electricity prices, NIMBY siting politics, and the progressive tax regime will combine to cause voters to elect politicians who build inefficiently dangerous power plants. Given these three factors, voters will select politicians who rig the rate-setting process to sell themselves cheap power. They will select politicians who site dangerous plants near a small minority of other voters. And they will select politicians who will charge any resulting catastrophe to the public fisc -and, thereby, to the small minority of taxpayers who fund the bulk of that fisc. They will not select politicians who equalize the cost and returns to the country as a whole.

\section{Conclusions}

On March 11, 2011, a magnitude 9.0 earthquake and 38 meter tsunami destroyed Tokyo Electric's nuclear complex on the shores of Fukushima. At the reactors, the fuel in the core began melting. The reactors leaked radiation into the air. They leaked it into the ground water. They leaked it into the sea. The result was a disaster -- but not a highdamage, low-probability disaster. It was a high-damage, high-probability disaster. Massive earthquakes and tsunami have assaulted the area every century.

Tokyo Electric could rationally do what it did because it did not pay the full cost of a catastrophic accident. Limited liability lies at the heart of corporate law, and limited liability let Tokyo Electric externalize the cost of running these nuclear reactors. In most industries, firms rarely undertake actions that risk tort damages so large that they cannot pay them. In the nuclear power industry, that potentially catastrophic liability is routine. Privately owned nuclear power companies bear the costs of an accident only up to the fire-sale value of their net assets. Beyond that point, they pay nothing.

Unfortunately, government ownership does no better. In modern democracies, most voters enjoy the benefit of cheap and stable electricity. Those same voters, however, bear little of the burden of the public fisc. Because any liability from a nuclear disaster would fall on the public fisc, they also bear little of the burden of any liability that a meltdown would cause. Under private ownership, shareholders of the power companies enjoy the revenue from nuclear reactors, but limited liability lets them escape the full liability of any damages they cause. Under government ownership, most voters enjoy the benefit of cheap and stable electricity, but progressive tax rates let them -- similarly -- escape the full liability of any damages they cause. 


\section{Table 1: Principal Nuclear Power Producers}

\begin{tabular}{llll} 
& $\begin{array}{l}\text { Elec'y } \\
\text { Gen'd }\end{array}$ & $\begin{array}{l}\text { Perct } \\
\text { Total }\end{array}$ & $\begin{array}{l}\text { Number } \\
\text { Reactors }\end{array}$ \\
\hline U.S. & 799 & 20.2 & 104 \\
France & 392 & 75.2 & 58 \\
Japan & 263 & 28.9 & 51 \\
Russia & 153 & 17.8 & 32 \\
S. Korea & 141 & 34.8 & 21 \\
Germany & 128 & 26.1 & 17 \\
All & & & \\
& 2560 & 13.8 & 440
\end{tabular}

Notes: The electricity generated is given in billion kilowatt-hours, 2009. The percent total gives the percentage of electricity generated, 2010. Number of reactors gives the number of operating reactors, April 2011.

Source: World Nuclear Association, World Nuclear Power Reactors \& Uranium Requirements, Apr. 2011. Available at: http://Www.worldnuclear.org/info/reactors.html 


\section{Table 2: Japanese Power Companies}

\begin{tabular}{lrrrr} 
& $\begin{array}{c}2010 \text { Net } \\
\text { Oper. Prof }\end{array}$ & $\begin{array}{c}2010 \text { Total } \\
\text { Assets }\end{array}$ & $\begin{array}{r}\text { Jan. } 2011 \\
\text { Mkt Cap }\end{array}$ & Capacity. \\
\hline Hokkaido Electric & 31.7 & 1,607 & 360 & $7,417 \mathrm{~mW}$ \\
Tohoku Electric & 89.3 & 3,919 & 916 & 15,770 \\
Tokyo Electric & 284.4 & 13,204 & 3,204 & 62,200 \\
Hokuriku Electric & 50.0 & 1,412 & 422 & 8,230 \\
Chubu Electric & 200.0 & 5,300 & 1,527 & 32,627 \\
Kansai Electric & 273.9 & 7,117 & 1,894 & 35,760 \\
Chugoku Electric & 81.5 & 2,781 & 619 & 4,210 \\
Shikoku Electric & 42.4 & 1,383 & 550 & 6,670 \\
Kyushu Electric & 98.9 & 4,185 & 872 & 19,330 \\
Okinawa Electric & 17.4 & 365 & 71 & 1,916
\end{tabular}

Notes: All financial figures in billion yen.

Source: Financial figures are calculated from the Nihon keizai shimbun. 